\title{
Lo Shiu-hing, Governing Hong Kong: Legitimacy, Communication and Political Decay
}

New York, Nova Science, 2001, XII+ 349 pp.

\section{Richard Baum}

\section{(2) OpenEdition}

\section{Journals}

Édition électronique

URL : http://journals.openedition.org/chinaperspectives/401

DOI : 10.4000/chinaperspectives.401

ISSN : 1996-4617

\section{Éditeur}

Centre d'étude français sur la Chine contemporaine

Édition imprimée

Date de publication : 1 août 2003

ISSN : 2070-3449

\section{Référence électronique}

Richard Baum, « Lo Shiu-hing, Governing Hong Kong: Legitimacy, Communication and Political Decay », China Perspectives [En ligne], 48 I july-august 2003, mis en ligne le 24 novembre 2006, consulté le 22 septembre 2020. URL : http://journals.openedition.org/chinaperspectives/401 ; DOI : https://doi.org/10.4000/chinaperspectives.401

Ce document a été généré automatiquement le 22 septembre 2020

(c) All rights reserved 


\title{
Lo Shiu-hing, Governing Hong Kong: Legitimacy, Communication and Political Decay
}

New York, Nova Science, 2001, XII+ 349 pp.

\author{
Richard Baum
}

Since the mid-1990s, no one has written about Hong Kong politics more prolifically or knowledgeably than Lo Shiu-hing. In this, his third book on the subject in the past six years (not to mention a fourth on the politics of Macau), Professor Lo examines the record of Hong Kong's post-retrocession political development. The story he tells is a sobering one. Although he finds that China has by and large formally honoured its promise to respect the "one country two systems" formula embedded in the 1990 Basic Law, Lo nonetheless sees Hong Kong's principal political trend since 1997 as one of steady "institutional decay", accompanied by creeping domination by Peking's appointed Hong Kong proxies. As Lo puts it boldly in his introduction, "Objectively speaking, the HKSAR's polity, economy and legal system have... deteriorated since the handover. Politically, the HKSAR is becoming more similar to the PRC than ever before" (p. 3).

2 Professor Lo's catalogue of Hong Kong's deteriorating conditions is a long and inclusive one: "Specifically, political decay in the HKSAR is characterized by a more personal style of governance; a chaotic implementation of public policies; an increasingly politicized judiciary [...]; endangered civil liberties [...]; an amalgamation of political labelling and mobilization; a failure of political institutions to absorb public pressure and demands; and a governmental insensitivity to public opinion" (p. 13). Now this is a rather imposing list of regime shortcomings. And it is clear from the outset that Professor Lo is not interested in sugarcoating his critical observations. In seven welldefined thematic chapters, he examines successively the British legacy, the socioeconomic environment, the civil service, the Chief Executive, the legislature, public opinion, and the role of Peking. Buttressing his arguments with a profusion of contemporaneous newspaper accounts and anecdotal evidence, as well as the 
observations of numerous Hong Kong-based analysts, he builds a strong case for Hong Kong's steady institutional deterioration and decay since 1997. There are two main problems with his analysis-neither of which necessarily bear on Lo's conclusions, which seem to me more or less sound, if perhaps too caustic and one-sided. The first problem is methodological, the second stylistic. Methodologically, Lo has perhaps unwittingly committed one of the cardinal sins of social science: selection bias. That is, he appears to have carefully chosen his evidence, his anecdotes, and his quotations to make the Hong Kong government of Chief Executive Tung Chee-hwa look as incompetent as possible - thereby bolstering his own pre-formed conclusions. Now it may be objected that it would be difficult to make the government of C.H. Tung look good no matter where you looked for evidence; but since Lo has looked mainly for bad news-finding a good deal of it-we will never know. Insofar as the book purports to be an objective account of Hong Kong's government and politics, its lack of balance is something of a liability.

3 Stylistically, the book suffers from a good deal of redundancy and some sloppy editing. The same arguments appear over and over, in slightly altered form, frequently accompanied by lengthy quotations from secondary sources. Much of this scholastic supporting material could have been excised (or abbreviated) with little or no loss of effect. It is as though Professor Lo felt duty bound to include every shred of evidence, every relevant quotation in his possession. His editor should have exercised a firmer hand.

4 Nevertheless, and despite these shortcomings, Governing Hong Kong is a useful book. Its slashing critique of the Tung administration's performance may be one-sided and overblown, but in view of the administration's inept handling of the recent SARS epidemic (among other failings), it may well be appropriate to point out that the HKSAR emperor's clothes are, well, very thin indeed. 